\title{
GENETIC DIFFERENTIATION BETWEEN AFRICAN AND EUROPEAN MIDWIFE TOADS (ALYTES, DISCOGLOSSIDAE)
}

\author{
by \\ J. W. ARNTZEN \\ Institute of Taxonomic Zoology, University of Amsterdam, \\ P. O. Box 20125, 1000 HC Amsterdam, The Netherlands
}

$\&$

\section{J. M. SZYMURA}

Department of Comparative Anatomy, Jagellonian University, Karasia 6, 30-060 Cracow, Poland

\begin{abstract}
SUMMARY
Toads of the genus Alytes from the Rif mountains in Morocco are electrophoretically very similar to Iberian Alytes obstetricans $\left(D_{\mathrm{Nei}}=0.07\right)$. Genetic distance estimates across the Straits of Gibraltar do not exceed the values found among European samples. The data point to relatively recent colonization or anthropogenic introduction of the Midwife Toad in Africa. The notion of Pasteur \& Bons (1962) that Alytes from the Rif mountains might represent a separate species is not corroborated.

\section{RÉSUMÉ}

Les crapauds du genre Alytes du Rif marocain sont similaires du point de vue électrophorétique à Alytes obstetricans de la Péninsule Ibérique $\left(D_{\mathrm{Nei}}=0,07\right)$. La distance génétique entre échantillons des deux côtés du détroit de Gibraltar n'est pas supérieure à celle séparant divers échantillons européens. Les données obtenues indiquent une colonisation relativement récente, ou bien l'introduction par l'homme du Crapaud accoucheur en Afrique, et elles ne confirment pas l'idée de Pasteur \& Bons (1962) que l'Alytes du Rif représenterait une espèce indépendante.
\end{abstract}

\section{INTRODUCTION}

The taxonomic position of the Midwife Toad from the Rif mountains in Morocco is puzzling. The differences found by Pasteur \& Bons (1962) in larval morphology and pigmentation led them to describe this form as Alytes [obstetricans] maurus sp. (vel ssp.) nov., which suggests this form may deserve recognition as a species separate from the European $A$. obstetricans (Laurenti, 1768). From the geological history of the western Mediterranean region it might be inferred that European and African populations of $A$. obstetricans have been separated since the Pliocene. At this time the Straits of Gibraltar broke through after a period in which the Mediterranean Sea had dried up (Hsü, 1972; Cita, 1982).

In anurans genetic differentiation is often accompanied by an apparent morphological stasis. We therefore studied allozyme variation in Alytes from the Rif mountains and seven European populations of $A$. obstetricans. We also included the Iberian Midwife Toad, $A$. cisternasi Boscá, 1879, in our analysis.

\section{MATERIALS AND METHODS}

The African Midwife Toads were collected from TletaKetama in the Rif mountains, Morocco. European samples of $A$. obstetricans were from Wenigerode (German Democratic Republic), Tübingen (Federal Republic of Germany), Arcy, Jublains and Bilhères (France), Covadonga (Spain) and Vilar Formoso (Portugal); $A$. cisternasii were from Córdoba (Spain). Sample localities are indicated in fig. 1. All samples are stored at the Institute of Taxonomic Zoology, Amsterdam (ZMA Herp. 7597, $7643,7644,7584,7645,7593,7602)$ except for the samples from Tübingen and Córdoba, which are stored at the Department of Comparative Anatomy of the Jagellonian University in Cracow.

We used starch gel electrophoresis in two buffer systems, LiOH, pH 8.1 and tris-citrate, pH 6.0 (nos. X and XIII, respectively, in Shaw \& Prasad, 1970), to study 13 enzymes from centrifuged liver-heart homogenate. The enzymes, visualized by standard histochemical techniques (e.g. Shaw \& Prasad, 1970) were encoded by 15 presumed loci: Glycerol-3-phosphate dehydrogenase E.C. 1.1.1.8 $(G p d)$; Lactate dehydrogenase E.C. 1.1.1.27 (Ldh-1 \& 2); Malate dehydrogenase E.C. 1.1.1.37 (Mdh); Malic en- 


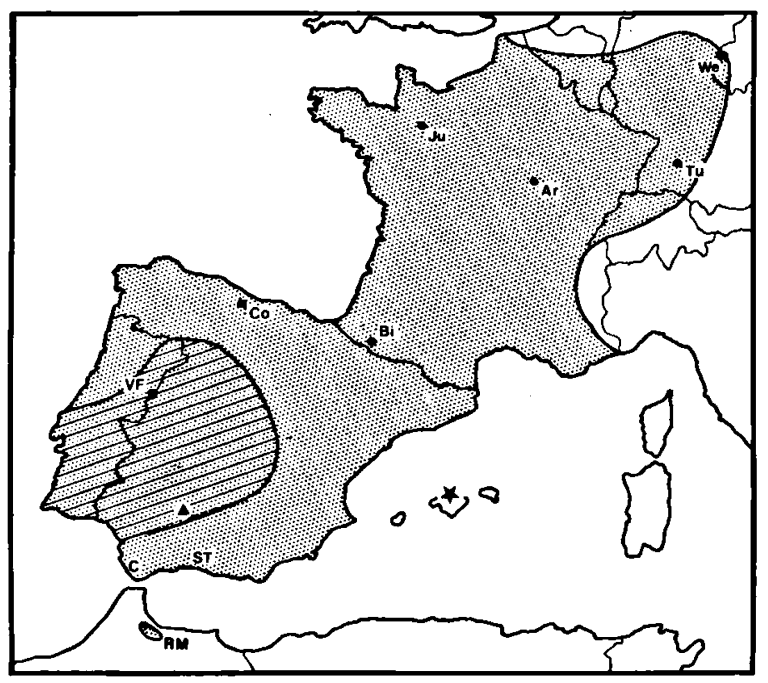

Fig. 1. Approximate distributions of Alytes: A. obstetricans (shaded), A. cisternasii (hatched) and $A$. muletensis (star). $A$. obstetricans and $A$. cisternasii have almost contiguous and mutual exclusive ranges, as has become clear from inventories in Portugal (Malkmus, 1983, 1984). A. obstetricans is not known from the Cádiz province (in figure indicated: C) (Busack, 1977), the species occurs however in the Sierra Tejeda (ST) at altitudes exceeding the $750 \mathrm{~m}$ level (Antúnez et al., 1982). Sample localities of $A$. obstetricans are: $\mathbf{W e}=$ Wenigerode, $\mathrm{Tu}=$ Tübingen, $A r=$ Arcy, $\mathrm{Ju}=$ Jublains, $\quad \mathrm{Bi}=$ Bilhères,$\quad \mathrm{Co}=$ Covadonga,$\quad \mathrm{VF}=$ Vilar Formoso, and RM = Tleta-Ketama, Rif mountains; the triangle indicates Córdoba, sample locality of $A$. cisternasii.

zyme E.C. 1.1.1.40 $(\mathrm{Me})$; Isocitrate dehydrogenase E.C. 1.1.1.42 (Icd-1 \& 2); Phosphogluconate dehydrogenase E.C. 1.1.1.44 (Pgd); Superoxide dismutase E.C. 1.15.1.1 (Sod); Glutamate oxaloacetate transaminase E.C. 2.6.1.1 (Got-1); Adenylate kinase E.C. 2.7.4.3 ( $A k)$; Phosphoglucomutase E.C. 2.7.5.1 (Pgm); Peptidase E.C. 3.4.11 (Pep, leucyl-tyrosine as substrate); Mannose phosphate isomerase E.C. 5.3.1.8 (Mpi); and Glucose phosphate isomerase E.C. 5.3.1.9 $(G p l)$. Presumptive loci and alleles were assigned numbers and letters, respective$\mathrm{ly}$, in sequence starting from the most anodally migrating forms.

\section{RESULTS}

Electromorph frequencies in Alytes samples are shown in table I. Apart from a monomorphic $G p d$ locus, we were able to resolve from two to six enzyme forms per locus. The number of polymorphic loci in separate samples was: one or two in Wenigerode, Tübingen, Arcy, Vilar
Formoso, and Rif mountains, five in Bilhères and six in Jublains, Covadonga, and Córdoba. The low level of variation in five of the populations can perhaps be attributed to either the peripheral position of the population (Wenigerode, Tübingen, Arcy, Vilar Formoso) or to genetic drift due to founder effect (R if mountains) (fig. 1). The other populations of $A$. obstetricans and $A$. cisternasii, which have about $1 / 3$ of their loci polymorphic, demonstrated levels of variation similar to, or exceeding those found in other amphibian populations (table II, cf. Avise \& Aquadro, 1982).

In order to assess the degree of genetic differentiation among the populations studied we used both Nei's standard genetic distance, $S G D$, and a modified genetic distance, known as minimum genetic distance, $M G D$, appropriate for our small sample sizes (Nei, 1978). SGD gives only slightly higher values than $M G D$ in comparisons among populations of $A$. obstetricans. In interspecific comparisons between $A$. obstetricans and $A$. cisternasii however, $S G D$ is about twice the value of $M G D$. The two methods of assessing degree of genetic divergences give nevertheless highly comparable matrices which have almost identical structure. In table II we report both $M G D$ and $S G D$ for comparison, but in the present paper the latter estimate is discussed.

Inspection of table I reveals that $\boldsymbol{A}$. cisternasii has different enzyme forms fixed at 10 out of 15 loci. The standard genetic distance between this species and $A$. obstetricans is 1.6. On the other hand, $A$. obstetricans populations have either the same electromorphs or share the most common ones at 12 loci. Few differences are found. The Rif population can be separated from the European samples by its unique MPI form. Similarly, the Sod locus allows us to distinguish the northern populations of $A$. obstetricans from the Iberian and Moroccan populations, as they have different electromorphs fixed. The same tendency can be seen at the polymorphic Pgd locus. The population from the Pyrenees (Bilhères) is polymorphic at both loci and might represent the centre of a cline. 
TABLE I

Electromorph frequencies for 15 loci in 8 populations of Alytes obstetricans and a single population of $A$. cisternasii.

\begin{tabular}{|c|c|c|c|c|c|c|c|c|c|c|c|}
\hline \multirow[b]{2}{*}{ locus } & \multirow[b]{2}{*}{$\begin{array}{l}\text { buffer* } \\
\text { system }\end{array}$} & \multirow[b]{2}{*}{$\begin{array}{l}\text { electro- } \\
\text { morph }\end{array}$} & \multicolumn{8}{|c|}{ 1lytes obstetricans } & \multirow{2}{*}{$\begin{array}{l}\text { A. cisternasii } \\
\\
\text { Córdoba } \\
\text { Spain } \\
N=5\end{array}$} \\
\hline & & & $\begin{array}{c}\text { Wenige- } \\
\text { rode } \\
\text { G.D.R. } \\
\quad N=3\end{array}$ & $\begin{array}{c}\text { Tübingen } \\
\text { F.R.G. } \\
N=3\end{array}$ & $\begin{array}{c}\text { Arcy } \\
\text { France } \\
N=3\end{array}$ & $\begin{array}{c}\text { Jublains } \\
\text { France } \\
\qquad N=5\end{array}$ & $\begin{array}{c}\text { Bilhères } \\
\text { France } \\
N=5\end{array}$ & $\begin{array}{l}\text { Cova- } \\
\text { donga } \\
\text { Spain } \\
N=5\end{array}$ & $\begin{array}{l}\text { Vilar } \\
\text { Formoso } \\
\text { Portugal } \\
\qquad N=5\end{array}$ & $\begin{array}{c}\text { Rif mts. } \\
\text { Morocco } \\
\quad N=5\end{array}$ & \\
\hline$G p d$ & XIII & $\mathbf{a}$ & 1.0 & 1.0 & 1.0 & 1.0 & 1.0 & 1.0 & 1.0 & 1.0 & 1.0 \\
\hline \multirow[t]{6}{*}{$L d h-1$} & XIII & $\mathbf{a}$ & - & - & - & - & - & 0.4 & - & - & 0.1 \\
\hline & & b & 1.0 & 1.0 & 1.0 & 1.0 & 1.0 & 0.6 & 1.0 & 1.0 & - \\
\hline & & c & - & - & - & - & - & - & - & - & 0.1 \\
\hline & & d & - & - & - & - & - & - & - & - & 0.3 \\
\hline & & $\mathbf{e}$ & - & - & - & - & - & - & - & - & 0.3 \\
\hline & & f & - & - & - & - & - & - & - & - & 0.2 \\
\hline \multirow[t]{3}{*}{$L d h-2$} & XIII & $\mathbf{a}$ & 1.0 & 1.0 & 1.0 & 1.0 & 1.0 & 1.0 & 1.0 & 1.0 & - \\
\hline & & b & - & - & - & - & - & - & - & - & 0.8 \\
\hline & & c & - & - & - & - & - & - & - & - & 0.2 \\
\hline \multirow[t]{4}{*}{$M d h$} & XIII & $\mathbf{a}$ & - & - & - & - & - & 0.2 & - & - & - \\
\hline & & b & 1.0 & 1.0 & 1.0 & 0.6 & 1.0 & 0.8 & 1.0 & 1.0 & - \\
\hline & & c & - & - & - & 0.4 & - & - & - & - & - \\
\hline & & d & - & - & - & - & - & - & - & - & 1.0 \\
\hline \multirow[t]{4}{*}{$M e$} & $x$ & $\mathbf{a}$ & - & - & - & - & - & - & - & - & 0.9 \\
\hline & & $\mathbf{b}$ & - & - & - & - & - & - & - & - & 0.1 \\
\hline & & c & - & - & - & - & - & - & - & 0.1 & - \\
\hline & & d & 1.0 & 1.0 & 1.0 & 1.0 & 1.0 & 1.0 & 1.0 & 0.9 & - \\
\hline \multirow[t]{2}{*}{$I c d-1$} & $\mathrm{X}$ & $\mathbf{a}$ & 1.0 & 1.0 & 1.0 & 1.0 & 1.0 & 1.0 & 1.0 & 1.0 & - \\
\hline & & b & - & - & - & - & - & - & - & - & 1.0 \\
\hline \multirow[t]{3}{*}{$I c d-2$} & $\mathrm{X}$ & $\mathbf{a}$ & - & - & - & 0.1 & 0.4 & - & - & - & 0.1 \\
\hline & & $\mathbf{b}$ & 0.3 & - & - & - & 0.2 & - & - & - & - \\
\hline & & c & 0.7 & 1.0 & 1.0 & 0.9 & 0.4 & 1.0 & 1.0 & 1.0 & 0.9 \\
\hline \multirow[t]{4}{*}{$P g d$} & $\mathrm{X}$ & $\mathbf{a}$ & 1.0 & 0.3 & 0.7 & 0.8 & 0.5 & 0.4 & - & - & - \\
\hline & & $\mathbf{b}$ & - & 0.7 & 0.3 & 0.2 & 0.5 & 0.6 & 1.0 & 1.0 & - \\
\hline & & c & - & - & - & - & - & - & - & - & 0.9 \\
\hline & & d & - & - & - & - & - & - & - & - & 0.1 \\
\hline \multirow[t]{3}{*}{ Sod } & X, XIII & $\mathbf{a}$ & 1.0 & 1.0 & 1.0 & 1.0 & 0.6 & - & - & - & - \\
\hline & & b & - & - & - & - & 0.4 & 1.0 & 1.0 & 1.0 & - \\
\hline & & c & - & - & - & - & - & - & - & - & 1.0 \\
\hline \multirow[t]{3}{*}{ Got-1 } & $\mathrm{X}$ & $\mathbf{a}$ & - & - & - & 0.1 & - & - & - & - & - \\
\hline & & b & 1.0 & 1.0 & 1.0 & 0.9 & 1.0 & 0.9 & 1.0 & 1.0 & - \\
\hline & & c & - & - & - & - & - & 0.1 & - & - & 1.0 \\
\hline \multirow[t]{3}{*}{$A k$} & $\mathrm{X}$ & $\mathbf{a}$ & - & - & - & - & - & 0.3 & 0.2 & - & - \\
\hline & & $\mathbf{b}$ & 0.2 & - & - & 0.2 & 0.4 & 0.3 & - & - & - \\
\hline & & c & 0.8 & 1.0 & 1.0 & 0.8 & 0.6 & 0.4 & 0.8 & 1.0 & 1.0 \\
\hline \multirow[t]{2}{*}{$P g m$} & $\mathrm{X}$ & $\mathbf{a}$ & 1.0 & 1.0 & 1.0 & 1.0 & 1.0 & 1.0 & 1.0 & 1.0 & - \\
\hline & & $\mathbf{b}$ & - & - & - & - & - & - & - & - & 1.0 \\
\hline \multirow[t]{2}{*}{$P e p$} & $\mathrm{X}$ & $\mathbf{a}$ & 1.0 & 1.0 & 1.0 & 1.0 & 1.0 & 1.0 & 1.0 & 1.0 & - \\
\hline & & b & - & - & - & - & - & - & - & - & 1.0 \\
\hline \multirow[t]{5}{*}{$M p i$} & $\mathrm{X}$ & $\mathbf{a}$ & - & 0.2 & - & 0.2 & 0.4 & 0.2 & - & - & - \\
\hline & & b & 1.0 & 0.8 & 1.0 & 0.8 & 0.6 & 0.8 & 1.0 & - & - \\
\hline & & c & - & - & - & $\rightarrow$ & - & - & - & - & 0.1 \\
\hline & & d & - & - & - & - & - & - & - & 1.0 & - \\
\hline & & e & - & - & - & - & - & - & - & - & 0.9 \\
\hline \multirow[t]{2}{*}{$G p i$} & XIII & $\mathbf{a}$ & - & - & - & - & - & - & - & - & 1.0 \\
\hline & & b & 1.0 & 1.0 & 1.0 & 1.0 & 1.0 & 1.0 & 1.0 & 1.0 & - \\
\hline
\end{tabular}

*f. Shaw \& Prasad (1970) 
TABLE II

Average heterozygosity $(H)$, standard genetic distance ( $S G D$, below diagonal), minimum genetic distance (MGD, to the right of the diagonal), and corresponding standard errors, calculated with A. K. Roychoudhury's computer program Gendis (Nei, 1978) from the data of table I.

\begin{tabular}{|c|c|c|c|c|c|c|c|c|c|}
\hline & $H$ & We & $\mathrm{Tu}$ & Ar & Ju & $\mathrm{Bi}$ & Co & VF & RM \\
\hline \multicolumn{10}{|l|}{ Alytes obstetricans } \\
\hline Wenigerode, G.D.R. (We) & $.06 \pm .04$ & - & $.03 \pm .03$ & $.01 \pm .00$ & $.01 \pm .01$ & $.04 \pm .02$ & $.11 \pm .07$ & $.14 \pm .09$ & $.20 \pm .11$ \\
\hline Tübingen, F.R.G. (Tu) & $.06 \pm .04$ & $.04 \pm .03$ & - & $.01 \pm .01$ & $.02 \pm .02$ & $.03 \pm .02$ & $.09 \pm .07$ & $.07 \pm .07$ & $.12 \pm .08$ \\
\hline Arcy, France (Ar) & $.03 \pm .03$ & $.01 \pm .01$ & $.01 \pm .01$ & - & $.01 \pm .01$ & $.04 \pm .02$ & $.10 \pm .07$ & $.10 \pm .07$ & $.16 \pm .09$ \\
\hline Jublains, France (Ju) & $.13 \pm .05$ & $.01 \pm .01$ & $.02 \pm .02$ & $.01 \pm .01$ & - & $.03 \pm .02$ & $.09 \pm .07$ & $.12 \pm .08$ & $.17 \pm .09$ \\
\hline Bilhères, France (Bi) & $.19 \pm .07$ & $.04 \pm .02$ & $.03 \pm .02$ & $.04 \pm .02$ & $.04 \pm .02$ & - & $.05 \pm .03$ & $.07 \pm .03$ & $.11 \pm .05$ \\
\hline Covadonga, Spain (Co) & $.18 \pm .07$ & $.13 \pm .09$ & $.10 \pm .09$ & $.11 \pm .08$ & $.11 \pm .09$ & $.06 \pm .04$ & - & $.03 \pm .01$ & $.09 \pm .06$ \\
\hline Vilar Formoso, Portugal (VF) & $.02 \pm .02$ & $.15 \pm .11$ & $.08 \pm .08$ & $.11 \pm .08$ & $.14 \pm .09$ & $.07 \pm .04$ & $.03 \pm .01$ & - & $.07 \pm .07$ \\
\hline Rif mts., Morocco (RM) & $.01 \pm .01$ & $.24 \pm .14$ & $.14 \pm .10$ & $.18 \pm .11$ & $.20 \pm .12$ & $.13 \pm .07$ & $.10 \pm .07$ & $.07 \pm .07$ & - \\
\hline total mean & $.16 \pm .05$ & & & & & & & & \\
\hline \multicolumn{10}{|l|}{ Alytes cisternasii } \\
\hline Córdoba, Spain & $.13 \pm .06$ & & & $S G D$ & $=1.6 \pm .53$ & $M G D=$ & $68 \pm .10$ & & \\
\hline
\end{tabular}

Standard genetic distances among $A$. obstetricans populations range from $S G D=0.01$ for neighbouring populations, to as high as $S G D=0.24$ between populations from Morocco and the German Democratic Republic. Across the Straits of Gibraltar $S G D=0.07$ only, a value not exceeding the distances among European samples. The degree of differentiation seems thus to be related to geographical distance.

\section{DISGUSSION}

We studied Alytes under the assumption that both the Moroccan Alytes and Alytes (Baleaphryne) muletensis (Sanchiz \& Adrover, 1977) from Mallorca were separated from the European mainstock at the beginning of the Pliocene, five million years ago, when the Straits of Gibraltar broke through and open marine conditions were re-established in the Mediterranean basin (Cita, 1982). We therefore expected to find comparable degrees of genetic differentiation for these pairwise comparisons. Yet despite the geographical isolation of the Moroccan population of Alytes, this population is electrophoretically very similar to our Iberian samples. The genetic distances among Moroccan and Iberian populations do not in fact exceed the values found among European populations (table II). A small immunological distance of three units has also been demonstrated between albumins from toads collected in the Rif mountains and Covadonga (Maxson \& Szymura, 1984).

On the other hand, $A$. cisternasii and $A$. muletensis are distinctly different from $A$. obstetricans in electrophoretic and immunological comparisons. As demonstrated in the present study, genetic distance between $A$. obstetricans and $A$. cisternasii is 1.6. The albumin immunological distance (AID) between the two taxa is 27 units (Maxson \& Szymura, 1984). A comparison of $A$. obstetricans and $A$. muletensis yielded an $A I D$ of 12 (Maxson \& Szymura, 1984). The degree of genetic divergence between $A$. muletensis and $A$. obstetricans is in good agreement with the amount expected to accumulate within five million years (Thorpe, 1982), the period of time passed since the separation of Mallorca from continental Europe. Thus the electrophoretical and immunological estimates of genetic divergence in Alytes point in the same direction.

Although it can not be excluded that the great genetic similarity of $A$. obstetricans on both sides of the Straits of Gibraltar indicates either invalid reconstruction of geological events or unequal mutation rates and wrong assumptions concerning the "molecular clock", it may well be a result of continued faunal exchange through rafting or anthropogenic introduction 
of this animal to Africa. The pattern of genetic differentiation of several amphibian and reptile species occurring on both sides of the Straits of Gibraltar is best explained by rafting, swimming, accidental transport (S. D. Busack, pers. comm.), or perhaps deliberate human introduction. The distribution of Chamaeleo chamaeleon (Linnaeus, 1758) on the Iberian peninsula is especially revealing; its known occurrence is in the vicinity of ports: Málaga, Gibraltar, Cádiz, Vila Real de Santo António (Klaver, 1981) and Faro (Malkmus, 1984). This pattern, in our opinion, points to anthropogenic introduction or accidental transport with ship cargoes. The genetic differentiation among African and Iberian chamaeleons is accordingly low: $S G D=0.06$ (A. Hofman, pers. comm.).

The habit of a male Midwife Toad in carrying developing eggs wrapped around his hindlegs makes it possible to establish a new population by a single individual only. The colonizing ability of Alytes may therefore be higher than that of other anurans and may equal the colonizing abilities of small terrestrial vertebrates with internal fertilization. The hypothesis of rafting, however, is not without difficulties as no Midwife Toads are known to occur at present in the close proximity of the Straits of Gibraltar (Bons, 1973; Busack, 1977). $A$. obstetricans occurs in southern Spain, e.g. in the Sierra Tejeda, but not below $750 \mathrm{~m}$ altitude (Antúnez et al., 1982). The known distribution of Alytes in Africa is restricted to an area high in the Rif mountains. The oversea distances from the mountains in southern Spain to the Rif mountains exceed by far the $13 \mathrm{~km}$ of the Straits of Gibraltar at its narrowest point.

The Midwife Toads, $A$. obstetricans, living north of the Pyrenees and those inhabiting the Iberian peninsula are considered by Mertens \& Wermuth (1960) to be representatives of two subspecies: $A$. o. obstetricans (Laurenti, 1768) and $A$. o. boscai Lataste, 1879, respectively. According to our samples these two groups can be distinguished by different enzyme forms at the Sod locus. The Midwife Toad from the Rif mountains, while having the SOD form indistinguishable from the form present in Por- tugal and Spain, can easily be diagnosed by its characteristic MPI electromorph. Therefore we think that the animals present in Africa most probably come from the Iberian peninsula and not from France, although the osteology and overt morphology of the adults resembles that of A. o. obstetricans and not that of $A$. o. boscai (cf. Pasteur \& Bons, 1962). This last observation, however, could not be confirmed by Crespo (1982). Our supposition is further evidenced by the study of buccal characters of larvae. A. 0 . obstetricans larvae of the appropriate size class from Wenigerode, German Democratic Republic ( $N=8$, ZMA Herp. 7631) and from the vicinity of Paris (Pasteur \& Bons, 1962) have single, double and triple tooth rows. Portuguese specimens of $A$. o. boscai have double, triple, and sometimes quadruple rows (Crespo, 1982). The Rif population with double, triple and quadruple tooth rows (Pasteur \& Bons, 1962) seems to fit in a north-south clinal variation. In conclusion, the results of the present study and our interpretation of the data do not support the notion of Pasteur \& Bons (1962) that Alytes from the Rif mountains could belong to a species (Alytes maurus) separate from Alytes obstetricans.

\section{ACKNOWLEDGEMENTS}

We like to thank Mr. C. Arntzen, Dr. J. Rafiński, Drs. G. Veenstra and our field companions for their help in collecting toads.

\section{REFERENCES}

Antúnez, A., J. M. Vargas \& J. Romero, 1982. Algunos datos sobre la reproducción de Alytes obstetricans Laur. en Sierra Tejeda (Andalucía). Publnes. Cent. pirenaico Biol. exp., 13: 47-49.

Avise, J. C. \& C. F. Aquadro, 1982. A comparative summary of genetic distances in the vertebrates. Patterns and correlations. Evolut. Biol., 15: 151-185.

Bons, J., 1973. Herpétologie marocaine, II. Origines, évolution et particularités du peuplement herpétologique du Maroc. Bull. Soc. Sci. nat. phys. Maroc, 53: 63-110.

Busack, S. D., 1977. Zoogeography of amphibians and reptiles in Cádiz province, Spain. Ann. Carnegie Mus., 46 (17): 285-316.

Crta, M. B., 1982. The Messinian salinity crisis in the Mediterranean: a review. In: H. Berckhemer \& K. Hsü eds., Alpine Mediterranean geodynamics. 
Geodynamics Series, 7: 113-140 (American Geophysical Union, Washington D.C.; Geological Society of America, Boulder, Colorado).

Crespo, E. G., 1982. Contribuição para o conhecimento da biologia das espécies ibéricas de Alytes, A. obstetricans boscai, Lataste 1879 e A. cisternasii, Boscá 1879 (Amphibia, Discoglossidae): morfologia dos adultos e dos girinos. Arq. Mus. Bocage, (C, Supl.) 1 (7): 255-312.

Hsü, H., 1972. When the Mediterranean dried up. Scient. Am., 227 (6): 26-36.

Klaver, C. J. J., 1981. Chamaeleo chamaeleon (Linnaeus 1758) - Gemeines oder Gewöhnliches Chamäleon. In: W. BöHmE ed., Handbuch der Reptilien und Amphibien Europas, 1. Echsen 1: 218-238 (Akademische Verlagsgesellschaft, Wiesbaden).

Malkmus, R., 1983. Nachtrag zur Verbreitung der Amphibien und Reptilien Portugals. Salamandra, 19: 71-83.

__, [1984]. Beitrag zur Verbreitung der Amphibien und Reptilien in Portugal. Salamandra, 18 “'1982”: 218-299.

Maxson, L. R. \& J. M. Szymura, 1984. Relationships among discoglossid frogs: an albumin perspective. Amphibia-Reptilia, 5 (in press).

Mertens, R. \& H. Wermuth, 1960. Die Amphibien und Reptilien Europas: i-xi, 1-264 (W. Kramer, Frankfurt am Main).

$\mathrm{NeI}, \mathrm{M}$., 1978. Estimation of average heterozygosity and genetic distance from a small number of individuals. Genetics, Princeton, 89: 583-590.

Pasteur, G. \& J. Bons, 1962. Note préliminaire sur Alytes [obstetricans] maurus: gemellarité ou polytopisme? Remarques biogéographiques, génétiques et taxinomiques. Bull. Soc. zool. Fr., 87: 71-79.

Shaw, C. R. \& R. Prasad, 1970. Starch gel electrophoresis of enzymes - A compilation of recipes. Biochem. Genet., 4: 297-320.

ThORPE, J. P., 1982. The molecular clock hypothesis: biochemical evolution, genetic differentiation and systematics. A. Rev. Ecol. Syst., 13: 139-168. 